DOI https://doi.org/10.30525/978-9934-26-172-5-2

\title{
ПЕРСПЕКТИВНІ НАПРЯМКИ РОЗВИТКУ \\ І ВИКОРИСТАННЯ ШТУЧНОГО ІНТЕЛЕКТУ ДЛЯ ПОТРЕБ СИЛ ОБОРОНИ ДЕРЖАВИ
}

\author{
Журавський Ю. В. \\ доктор технічних наук, старший науковий співробітник, \\ начальник кафедри електротехніки та електроніки \\ Житомирський військовий інститут імені С. П. Корольова \\ м. Житомир, Украӥна
}

\author{
Кошлань О. А. \\ доктор філософії, \\ провідний науковий співробітник
}

науково-методичного відділу аналізу та прогнозу освітньої діяльності Національний університет оборони України імені Івана Черняховського м. Київ, Украӥна

\section{Нікітенко А. П.}

доктор філософії,

старший викладач кафедри оперативного мистецттва

Наџіональний університет оборони Украӥни імені Івана Черняховського

м. Київ, Україна

Підхід до автоматизації процесів управління силами і засобами в оборонній сфері, заснований на використанні традиційних методів формалізації і алгоритмізації, стає недостатньо ефективним і адекватним в управлінських ситуаціях, що виникають при веденні збройної боротьби в умовах все більш значущих проявів різних факторів невизначеності та ризиків [1-5].

При подальшому розвитку системи управління військового призначення проблеми використання традиційних формалізованих методів і управлінських моделей будуть тільки все більше ускладнюватися i, відповідно, посилюватися, ставати пристосованими до все меншого і меншого спектру сучасних і очікуваних завдань управління, зразків озброєння і військової техніки, які наближаються до своїх граничних можливостей при використанні традиційних фізичних процесів їх побудови. Виникає потреба у розробці принципово нових 
управлінських підходів у тому числі 3 застосуванням технологій штучного інтелекту.

Мета дослідження полягає в визначенні перспективних напрямків розвитку і використання штучного інтелекту для потреб сил оборони держави.

Високий рівень інформаційного забезпечення операційних (бойових) дій військ (сил) стає визначальним фактором досягнення стратегічної, оперативної і тактичної переваги над противником. У концепції інформаційного протиборства особлива роль відводиться технічній розвідці, радіоелектронній боротьбі і операціям в кіберпросторі, забезпеченню інформаційної переваги над противником і власної інформаційної безпеки в цілому.

Угруповання військ (сил) є складними організаційно-технічними системами, що складаються 3 різнорідних організаційно-структурних компонентів, які повинні бути сумісними між собою i керовано сполучатися таким чином, щоб забезпечувалася їх адекватність динаміці зміни обстановки в районі ведення бойових дій.

Усе це буде принципово до обставин, які змушено здійснюються в умовах існування невизначеності і прояви факторі ризику. Для цього необхідна скоординована програмна підтримка прийняття управлінських рішень 3 використанням сучасних технологій i методів штучного інтелекту та інформаційно-телекомунікаційних технологій на основі реалізації більш узгодженої і організованої взаємодії між собою різнорідних сил і засобів, що входять в об'єднані (міжвидові) і видові угруповання, які безпосередньо беруть участь в операціях (бойових діях).

Напрямками застосування штучного інтелекту для потреб сил оборони держави $€[1-5]$ :

- моделювання ведення бойових дій i обгрунтування складу в операціях (бойових діях) сил і засобів, які задіються;

- функціонування інтегрованих систем розвідки i керування, дистанційно-керованих розвідувально-ударних бойових комплексів, робототехнічних систем військового призначення;

- управління мобільними розвідувальними системами бойової охорони заданих рубежів і об'єктів;

- інтелектуальні технології ситуаційного управління військовими роботами, ударно-розвідувальними безпілотними літальними апаратами, розвиток математичних методів інтелектуального пошуку і аналізу інформації, в тому числі розвідувального характеру, розвиток теорії i методів прийняття управлінських рішень в складних динамічних ситуаціях в реальному масштабі часу, в тому числі при управлінні структурною динамікою угруповань при веденні операцій (бойових дій); 
- створення ефективних методів розпізнавання мови в умовах обмеженої смуги частот, наявності шумів і т.п.;

- технології радіолокаційного спостереження, побудовані на інтелектуальних методах обробки інформації від низькочастотних радіолокаційних станцій (метрового i дециметрового діапазонів), що дозволяють виявляти найменші ознаки наявності цілей в відображених радіолокаційних сигналах;

- моделі групового, мережевого і “ройового” управління, управління системами оборони і нападу;

- комплекси протиповітряної оборони;

- інтелектуальні інформаційні послуги щодо забезпечення розвідувальною інформацією, оцінювання обстановки, планування та управління бойовими діями, забезпечення взаємодії, координації та субординації;

- оцінювання стану (фізичного, психофізіологічного і психічного) військовослужбовців у повсякденній і бойовій діяльності з використанням інтелектуальних алгоритмів розпізнавання і оцінювання функціональних і депресивних станів військовослужбовців, що забезпечує своєчасне виявлення можливості неадекватної поведінки військовослужбовців і запобігання негативних його наслідків

- системні завдання інтелектуалізації управління розподіленими багатокомпонентними (багатоструктурними) системами військового призначення на основі узгодженої взаємодії їх структурнофункціональних компонентів і т.д.

Зазначений перелік не є вичерпним та буде доповнений у подальших наукових дослідженнях авторів.

Більшість складних процесів у військовій справі характеризується різними видами невизначеності, багатозначністю ситуацій, багатоваріантністю можливих управлінських рішень і їх наслідків, розмитістю, слабкою або неможливою алгоритмізацією і формалізацією.

Подальший розвиток різноманітних систем військового призначення буде тільки ускладнювати i посилювати проблеми використання традиційних методів і обумовлювати необхідність застосування методів і технологій штучного інтелекту.

\section{Література:}

1. Koshlan A., Salnikova O., Chekhovska M., Zhyvotovskyi R., Y. Prokopenko, T. Hurskyi, A. Yefymenko, Y. Kalashnikov, S. Petruk, A. Shyshatskyi. Development of an algorithm for complex processing of geospatial data in the special-purpose geoinformation system in conditions of diversity and uncertainty of data. Eastern-European Journal of Enterprise 
Technologies. Vol. 5. No. 9 (101). 2019. pp. 16-27. DOI: https://doi.org/10.15587/1729-4061.2019.180197.

2. Shyshatskyi A., Tiurnikov M., Suhak S., Bondar O., Melnyk A., Bokhno, T., \& Lyashenko, А.. Методика оцінки ефективності системи зв'язку оперативного угруповання військ. Сучасні інформаційні системи. 2020. Том 4, № 1, с. 107-112. https://doi.org/10.20998/25229052.2020.1.16.

3. Демидов Б. А., Гриб Д. А., Хмелевская О. А. Концептуальные аспекты информатизации и автоматизации управления в вооруженных силах государства. Збірник наукових праць Харківського національного університету Повітряних Сил. 2017. № 5(54). С. 38-43.

4. Гриб Д. А., Демідов Б. О., Борисенко М. В., Кузнєцова М. Ю. Інформатизація управління структурною динамікою складних багато структурних систем військового призначення при динамічній зміні обстановки в районі ведення бойових дій. Збірник наукових праць Харківського національного університету Повітряних Сил. 2019. № 2(60). C. 7-15. https://doi.org/10.30748/zhups.2019.60.01.

5. Демідов Б. О., Кучеренко Ю. Ф., Матющенко О. Г. Основні напрямки застосування технологій, що містять елементи та методи штучного інтелекту, в оборонній сфері. Наука і техніка Повітряних Сил Збройних Сил України. 2018. № 4(33). С. 7-15. https://doi.org/10.30748/ nitps.2018.33.01.

DOI https://doi.org/10.30525/978-9934-26-172-5-3

\title{
ANALYSIS OF THE CURRENT ATTITUDE TO THE AUTOMATION OF THE FLIGHT PLANNING SYSTEM
}

\author{
Kolesnyk A. V. \\ Candidate of Technical Sciences, \\ Senior Lecturer at the Department of Information Technologies \\ Flight Academy of the National Aviation University \\ Kropyvnytskyi, Ukraine
}

In the flight planning process, the air traffic controller uses specialized software for planning the flight, monitoring the flight process and informing the crew of any circumstances that may affect flight safety.

The effectiveness of the current flight planning system depends on how close the developed flight route is to the optimal option in terms of achieving 12 